

Publisher

http://jssidoi.org/esc/home

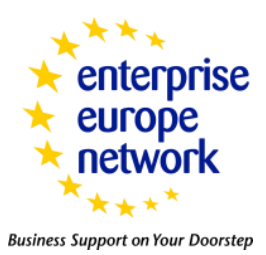

CASPA

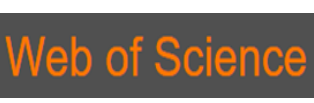

\title{
IMPACT OF PRODUCTION AND TRANSACTION COSTS ON COMPANIES' PERFORMANCE ACCORDING ASSESSMENTS OF EXPERTS
}

\author{
Petrenko Elena ${ }^{1}$, Sergey Pizikov ${ }^{2,}$ Nurlan Mukaliev ${ }^{3}$, Anuar Mukazhan ${ }^{4}$ \\ ${ }^{1}$ Plekhanov Russian University of Economic, 117997, Moscow, Stremyanny lane 36, Russia \\ ${ }^{2}$ Founadion for Informational Support for Society Development East Kazakhstan, 070018, Ust-Kamenogorsk city, \\ Voroshilov str., 165, of. 20 Kazakhstan \\ 3"VIMA" LLP Alash highway, 7, Baikonur Area, Astana Z01C1Y8, Kazakhstan \\ ${ }^{4}$ Tsesnabank JSC, 24 Syganak st., Astana Z05K7BO, Kazakhstan \\ E-mails: ${ }^{1}$ petrenko_yelena@bk.ru, 2pizikov.s@gmail.com; ${ }^{2}$ mu7kaliev@mail.ru, \\ 4anuar.mukazhanov@gmail.com
}

Received 10 March 2018; accepted 15 August 2018; published 30 September 2018

\begin{abstract}
Kazakhstan now actively supports the development of entrepreneurship and conducts diversification of the economy. However, the recent crisis has changed the world market and business performance in the country has deteriorated significantly. The presented research studies the directions and reasons for the growth of costs. Based on a mass survey of entrepreneurs, the impact of production and transaction costs on the activities of businesses was assessed. Reducing administrative barriers should also reduce costs across the entire front line between government and business. However, in the process of decisions development on priority areas for reducing costs, evaluations of experts unite and lose coherence. Economic assessments turn into political ones, while the degree of consensus (concordance) of opinions is low. This limits the reliability of the final data and the possibility of their application. In this study, the consistency assessment was carried out using the concordance coefficient.
\end{abstract}

Keywords: entrepreneurship; business; production costs; transaction costs; survey; experts; consistency assessment; concordance; Kazakhstan

Reference to this paper should be made as follows: Petrenko, E.; Pizikov, S.; Mukaliyev, N.; Mukazhan, A. 2018. Impact of production and transaction costs on companies' performance according assessments of experts, Enterpreneurship and Sustainability Issues 6(1): 398410. http://doi.org/10.9770/jesi.2018.6.1(24)

..

JEL Classifications: C81, C83 


\section{Introduction}

For a long time, cost management in Kazakhstan was seen as an internal issue of enterprises, and the state's task was to create favorable conditions for economic activities. The free market and competition stimulate the business to obtain higher profit rates and should become the basis for increasing production efficiency.

The formation and development of Kazakhstan's business took place against the backdrop of an increase in commodity prices, which ensured the growth of the economy as a whole. Under such favorable conditions, Kazakhstani business was not focused on lean production, as well as state bureaucratic machine was not oriented to save state budget funds.

As a result, Kazakhstani enterprises operate at low productivity and spend more financial and material resources than business in the advanced countries of the world. The first wave of the crisis of 2007-2010 made the sanation of the most vulnerable places in the domestic economy, but a protracted recession did not ensured any significant increase in labor productivity and cost reduction (OECD 2017). The second wave of the crisis, which occurred in 2015, showed that the possibilities for savings are exhausted. From the local reduction of administrative barriers, it is necessary to move on to systemic work to prevent their occurrence and frontal cost reduction, including both reducing the administrative burden, and optimizing the cost structure according to the advanced regulatory level (Akorda.kz,2017).

In 2015, total expenses (excluding Corporate Income Tax) of businesses over 100 employees increased by 33\% at once, while total expenses of small business grew up to 43\% (CEO SURVEY 2016). The largest increase in the cost structure of large and medium-sized businesses occurred under the item "other expenses", which increased from $41.7 \%$ to $53.7 \%(+12 \%)$. In small business, "other expenses" reached $63.4 \%$ in 2015 with an increase of $9.7 \%$ over 6 years.

Other expenses consist of taxes, compulsory levies, rents, services of outside organizations (non-productive services), costs of bank loans, representation and hospitality, etc. Increasing "other expenses" reflects the strengthening of the administrative burden and deterioration of the institutional environment for doing business in Kazakhstan.

It should be noted that there is no systematic macroeconomic accounting of costs in Kazakhstan's statistics, which also indicates insufficient attention paid to cost analysis. Lack of reliable and comparable statistics makes impossible to determine the dynamics of costs and monitor them (Tvaronavičienè, Nesterova, Kováčik, 2017). Benchmarking is an important factor in improving production efficiency, but in this case even comparison with Kazakhstan indicators is impossible, since the costs by sectors are not determined on an ongoing basis.

In 2017, the authors participated in a large-scale national study, which examined various aspects of the development of Kazakhstani entrepreneurship and its costs. To assess the level of costs and analyze the current situation, combined research methods were applied, including and combining desk assessment, factor analysis, peer (expert) review, pilot study and others.

\section{Methodology}

Generally, business costs can be divided into production costs and transaction costs. Cost - monetized form of expenditure of different types of economic resources (raw materials, labor, fixed assets, services, financial resources), as well as related to the obligations and requirements of the state in the production and circulation of products and goods. 
(In business, cost is usually a monetary valuation of (1) effort, (2) material, (3) resources, (4) time and utilities consumed, (5) risks incurred, and (6) opportunity forgone in production and delivery of a good or service. All expenses are costs, but not all costs (such as those incurred in acquisition of an income-generating asset) are expenses.

Production costs - the costs related to the production of goods. In accounting and statistics they are reflected like prime cost (net cost). Include raw material costs, labor costs, etc.

Administrative costs (term is often used as a synonym for Transaction costs) are costs that are not directly involved in the production of goods, but are indirect costs to fulfill obligations and requirements (established by government) related to the collection and retrieval of information, the conclusion of transactions, contracts, contracts, etc. (Paneyah, 2001).

For purposes of this study of costs of the Kazakhstani businesses and their (costs) frontal decline (reduction), Standard Cost Model (SCM) is used, which allows to reduce the level state regulation as well as existing relations between business on one hand, and natural monopoly entities and the quasi-public sector on another hand.

Two groups of respondents were surveyed:

- Entrepreneurs (owners either top managers) who were asked to estimate the potential and real impact of costs; - Specialists in finance and/or accounting to assess the level of growth (decrease) in costs and determine their priority in terms of their impact on the business.

The questionnaire for business owners and/or top managers is more evaluative, emotional in nature and is aimed to obtain not so much facts about the magnitude of costs, but more respondents' opinion on how these costs affect the efficiency (and sometimes the viability even) of business. The opinion of entrepreneurs reflects thus their intention to develop, manage or, on the contrary, close the business.

Financiers/accountants are the category of respondents, who best of all (sometimes even better than owners) have information about the amount of payments, their frequency, etc. Therefore, the questionnaire for them is aimed to obtain information about the types and magnitude of costs. Researchers admitted that to fill in this questionnaire might be necessary to apply to the accounting and financial documents, that this may require the work of more than one person, etc.

In both versions, the questionnaire contained open and closed questions The costs increasing was estimated a) as a percentage of increment; and b) depending on the Likert-type scale. The scale contained the following assessments:

- costs have not changed,

- rose up to $10 \%$,

- increased up to $10-20 \%$,

- increased up to $20-30 \%$,

- increased more than $30 \%$,

- I can not answer.

Thus, using the two above questionnaires, the authors obtained two sets of data on the same types of costs. Comparison of these groups of data quite clearly and reasonably shows the influence of various costs on the daily life of business. This approach allows the most complete reflection of the real situation at businesses in different industries, different dimensions (large/medium/small) and stages of development. 
The general number of businesses in Kazakhstan is 1.1 million (The Prime Minister of Kazakhstan, 2018)

The sample with a confidence level of $97 \%$ and an acceptable sampling error of $2 \%$ is 2963 businesses. According to quotas, the sample included 2496 small and medium-sized enterprises and 281 large ones.

Quotas by industry were determined taking into account the share of enterprises in GDP, since costs are part of the finite cost of the product.

The actual sample obtained corresponds to the planned indicators and is completely representative.

The survey was conducted in 2017, as a result of which 2777 entrepreneurs and 2769 accountants turned out to be suitable for further processing.

The structure of business by industry in the manufacturing and service sectors is presented in Figures 1 and 2 below.

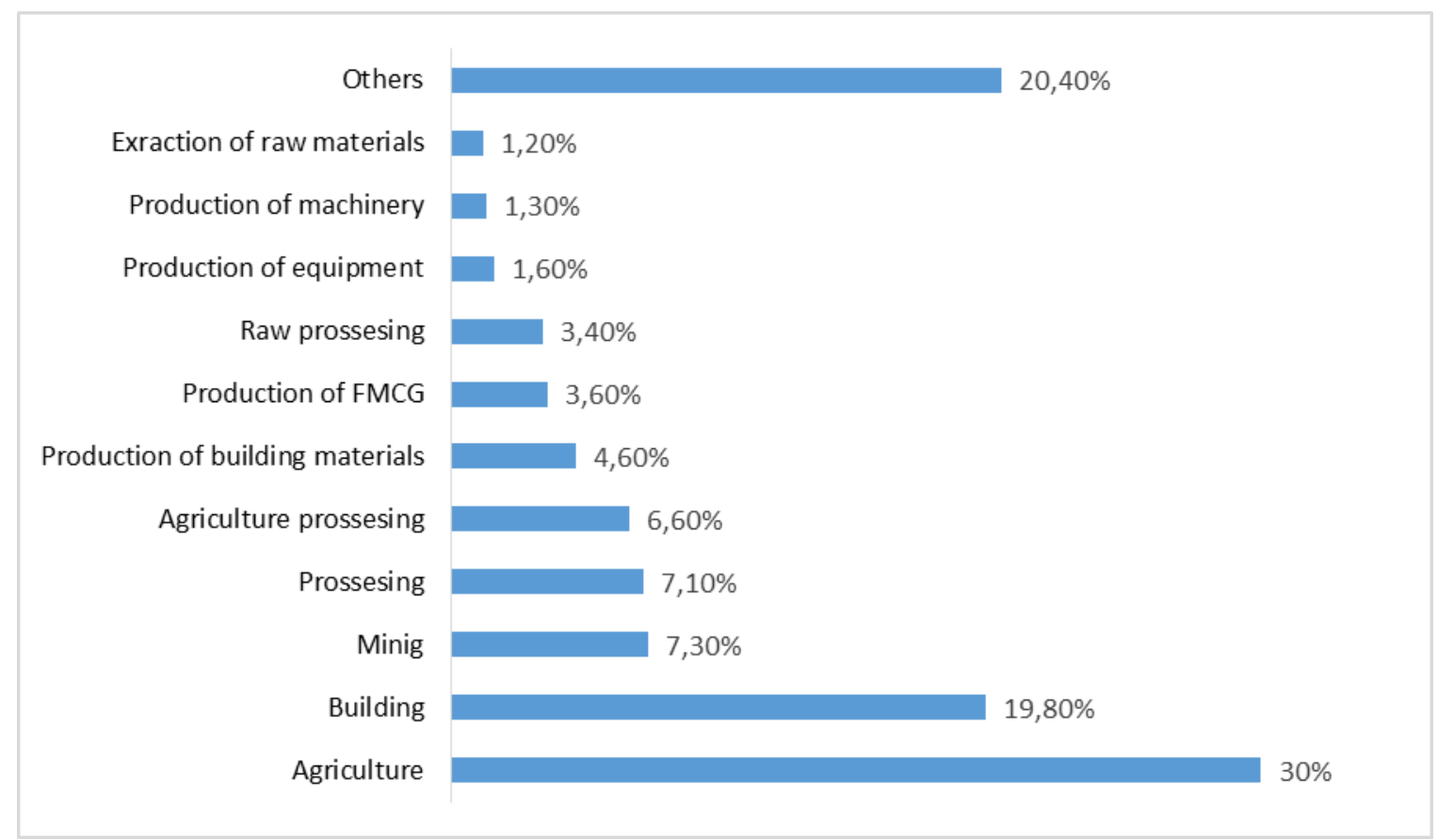

Figure 1. Sample structure by industry: Manufacturing sector Source: personal elaboration 


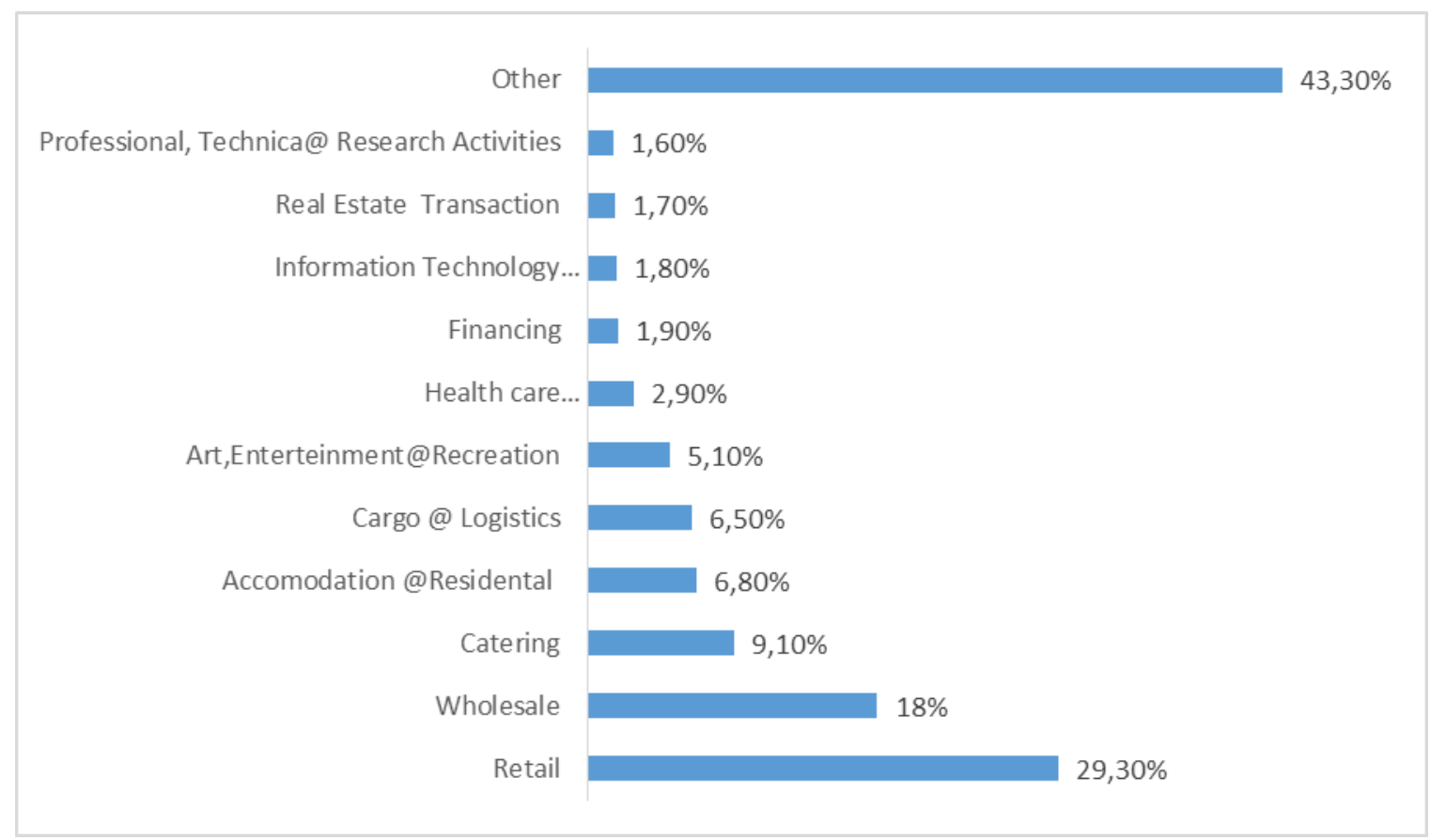

Figure 2. Sample structure by industry: Services sector Source: personal elaboration

As can be seen from the presented diagrams, the most significant share of respondents in the manufacturing sector falls on businesses engaged in agriculture (30\%) and construction (19.8\%). As for service sector, retail and wholesale trade prevail there $(29.1 \%$ and $18 \%)$.

A high proportion of "other" activities, both in production and in services, attract attention. In the author's opinion, this fact reflects the specifics of the development of entrepreneurship, which chooses various forms and directions of activity in the conditions of the "catch-up development" economy.

\section{Analysis}

Production costs were assessed in terms of their influence on the overall performance of business, its competitiveness and profitability. Various items of production costs were considered by their strength of the impact and the risk of significant losses and even bankruptcy. It was assumed that if businesses massively begin to feel a strong burden of cost growth, this creates a threat to the entire state economy and requires systemic state intervention and cost-cutting efforts by the entire front line.

The activity of any enterprise assume the consumption of raw materials, energy, payment of wages, social and pension insurance of employees, accrual of depreciation, as well as with a number of other necessary costs. All these costs are reimbursed through the sale of products (goods, services). These costs are production costs, or costs directly related to the production of goods or services.

The authors assumed that a critical increase in costs is $25 \%$ - if this value is exceeded, negative changes begin for the economy as a whole. 
Respondents' opinions are subjective, but if they in total exceed the threshold, they represent a statistically significant public opinion of the business community.

The valuation was carried out for 18 items of production costs, in the context of industries and services. Also, the structure and dynamics of business costs of different size and stage of the life cycle were compared.

The increase in production costs associated with the purchase of raw materials, components has a strong impact on the business of almost half of the respondents (47,4\%), of which a very strong influence is felt by $13.5 \%$, and critical - by $2.8 \%$. Insignificant influence is felt for $22.6 \%$ of respondents. These costs do not affect each third entrepreneur.

In accordance with the proposed approach, the authors singled out the share of organizations in which the costs increased by more than $25 \%$. (Recall, such growth was defined as critical, capable of adversely affecting business activities) - Table 1 .

Table 1. The share of organizations with a growth in production costs of more than $25 \%$

\begin{tabular}{|c|c|c|c|}
\hline$№$ & Costs & Manufacturing Sector & Services Sector \\
\hline 1 & Raw materials & 48 & 33 \\
\hline 2 & Salary of production workers & 31 & 23 \\
\hline 3 & Salary of auxiliary workers & 18 & 16 \\
\hline 4 & Depreciation & 37 & 14 \\
\hline 5 & Auxiliary materials & 22 & 11 \\
\hline 6 & Social package for workers & 15 & 27 \\
\hline 7 & Fuel & 50 & 22 \\
\hline 8 & Transportation & 38 & 35 \\
\hline 9 & Electricity & 39 & 34 \\
\hline 10 & Heating & 26 & 23 \\
\hline 11 & Water/Sewage & 25 & 13 \\
\hline 12 & Trash & 13 & 27 \\
\hline 13 & Bank payments & 12 \\
\hline 14 & Communications & 34 & 11 \\
\hline 15 & Lease, renting & 15 & 23 \\
\hline 16 & Licenses & 18 & 37 \\
\hline 17 & Taxes & 23 & 23 \\
\hline 18 & Social payments & 32 & \\
\hline
\end{tabular}

Source: personal elaboration

According to surveyed entrepreneurs, a significant problem for business development is primarily the growing prices for fuels, electricity, raw materials. A quarter to a half of the respondents both in manufacturing and services sectors named these costs as a serious obstacle in their current activities. $38 \%$ of the respondents in manufacturing businesses indicated high transportation costs. Businesses in the service sector noted an unfavorable level of taxes and payments, which, according to their assessment, is in the first place as a deterrent to the development of service entrepreneurship. Loans are also a common problem for industry and services (Figure 2).

Transaction costs are costs that do not relate directly to the production of products, but are associated with collecting and searching for all the information necessary for the activity, concluding various transactions, and etc.(Giriūnienè, Giriūnas, 2017). Transaction costs are barriers to doing business and its development, so resolving problems associated with transaction costs and reducing these costs will create a favorable business 
climate and good conditions for the development of the business environment (Ketokivi, Mahoney, 2017; Narkunienè, Ulbinaitè, 2018)

The increase in such transaction costs, as the costs of property protection, does not affect business in the opinion of $54.8 \%$ of respondents. $28 \%$ of entrepreneurs believe that the influence is weak. $17.2 \%$ of respondents said about a more significant influence, while $3.8 \%$ only said they have a strong influence

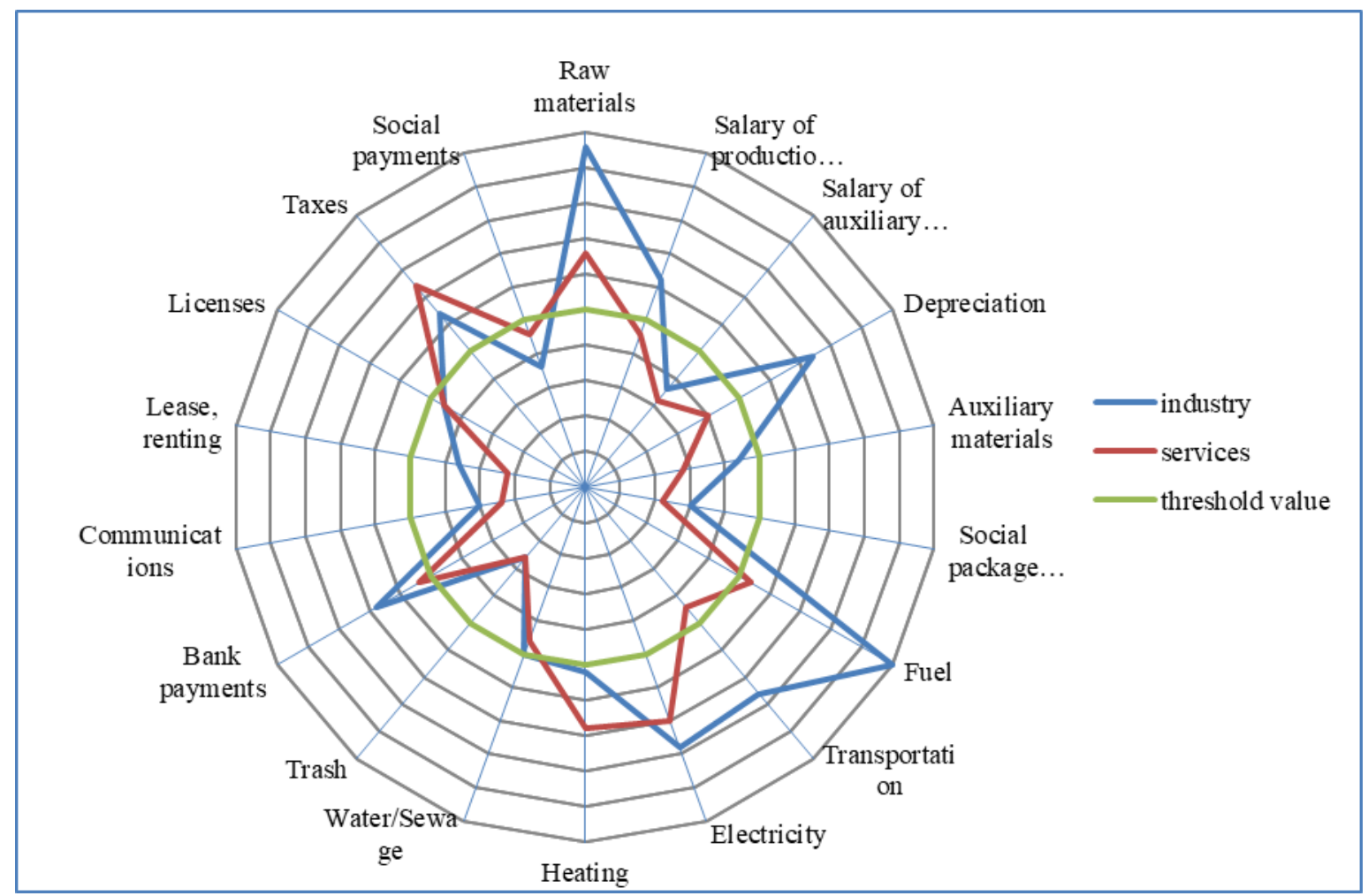

Figure 3. The impact of transaction costs on business operations Source: personal elaboration

Entrepreneurs consider raising the salaries of the main staff like significant costs. Obviously, the increase in pay and the transition to a full social package is not accompanied by increased productivity and increased labor motivation of employees.

At the next stage of the analysis, the degree of influence of various cost items on the state of the business was ranked for each category of experts. Ranking the significance allowed to translate the statistical evaluation into a social one.

Since the main task of the national research was to improve the situation in Kazakhstani business through the adoption of new laws and regulations, the choice of priorities has not only economic but also political significance. 
Improving the institutional environment requires significant resources, concentrated in a number of areas, possibly at the expense of others. The coordination of interests of various stakeholders in lobbying legislative reforms should be based on the agreed opinion of the beneficiaries. It was very important to correctly determine the cost items that have a key effect on the growth (decrease) in costs.

As a result of grouping, TOP-10 items of production costs and TOP-12 of the most significant items of transaction costs were singled out. Also, businesses were grouped according to belongings to the services sector or manufacturing sector.

Since the survey was conducted on two categories of experts - property owners (managers) and specialists (accountants, economists, financiers) - the rankings of these two groups were additionally allocated. The results of ranking are presented in Table 2 .

Table 2. Ranking of costs by the degree of influence

\begin{tabular}{|c|c|c|c|c|c|}
\hline \multirow[t]{3}{*}{ № } & \multirow[t]{3}{*}{ Costs } & \multicolumn{4}{|c|}{ Experts } \\
\hline & & \multicolumn{2}{|c|}{ Manufacturing } & \multicolumn{2}{|c|}{ Services } \\
\hline & & Owners & Specialists & Owners & Specialists \\
\hline & \multicolumn{4}{|c|}{ Production costs } & \\
\hline 1 & Raw materials & 2 & 1 & 4 & 1 \\
\hline 2 & $\begin{array}{c}\text { Salary of production } \\
\text { workers }\end{array}$ & 8 & 6 & 9 & 9 \\
\hline 3 & Depreciation & 5 & 5 & 10 & 10 \\
\hline 4 & Fuel & 1 & 9 & 5 & 8 \\
\hline 5 & Transportation & 4 & 2 & 8 & 7 \\
\hline 6 & Electricity & 3 & 4 & 2 & 6 \\
\hline 7 & Heating & 9 & 3 & 3 & 4 \\
\hline 8 & Water/sewage & 10 & 7 & 7 & 5 \\
\hline 9 & Bank payments, Loans & 6 & 8 & 6 & 2 \\
\hline \multirow[t]{2}{*}{10} & Taxes, other payments & 7 & 10 & 1 & 3 \\
\hline & \multicolumn{5}{|c|}{ Transaction costs } \\
\hline 1 & Certification & 4 & 7 & 12 & 8 \\
\hline 2 & Fines & 2 & 4 & 1 & 2 \\
\hline 3 & Legal (court) costs & 12 & 3 & 5 & 3 \\
\hline 4 & $\begin{array}{l}\text { Access to state } \\
\text { procurements }\end{array}$ & 3 & 6 & 11 & 9 \\
\hline 5 & Access to finance (loans) & 1 & 5 & 4 & 5 \\
\hline 6 & Bribes to officials & 5 & 10 & 8 & 10 \\
\hline 7 & Bribes to bank officers & 6 & 11 & 9 & 11 \\
\hline 8 & $\begin{array}{c}\text { Bribes to employees of } \\
\text { enterprises that are subjects } \\
\text { of natural monopolies }\end{array}$ & 7 & 12 & 10 & 12 \\
\hline 9 & Security costs & 10 & 8 & 7 & 4 \\
\hline 10 & Tax reporting & 11 & 9 & 2 & 7 \\
\hline 11 & $\begin{array}{l}\text { Reporting to government } \\
\text { agencies (non-tax) }\end{array}$ & 9 & 1 & 6 & 1 \\
\hline 12 & Payments for permits ${ }^{*}$ & 8 & 2 & 3 & 6 \\
\hline
\end{tabular}

Source: Personal Elaboration

\footnotetext{
*Four types of payments are included here: 1 - government's permits, 2 - natural monopolist's permits, 3 - quasi state permits, 4 - inspections costs.
} 
The International Journal

ENTREPRENEURSHIP AND SUSTAINABILITY ISSUES

ISSN 2345-0282 (online) http://jssidoi.org/jesi/ 2018 Volume 6 Number 1 (September) http://doi.org/10.9770/jesi.2018.6.1(24)

Expert opinions represent the cumulative assessment given by large number of respondents-representatives of Kazakh entrepreneurship and managerial specialists. They can be used to represent the interests of the whole national business and become the basis for making decisions on changing the legislation affecting the conditions of doing business in the whole country. In this regard, it is important to assess how consentaneous (concordant) the expert opinion is when combining the results of the questionnaire into the overall assessment. The task is of great applied value, since in practice, mass questioning and interviewing of various representatives of business are often used. According to author's estimates, up to 50 national polls of entrepreneurs are conducted annually in Kazakhstan, as well as about 200 polls at the regional level.

At the same time, an assessment of the consistency of opinions of different respondents is carried out for the first time in Kazakhstani science and practice.

The results of the assessment will help public organizations to determine the relevance of the requirements of various business groups and organizations, and researchers of the business environment - more accurately conduct surveys and reduce the cost of processing them. The assessment of the concordance of experts' opinions can be made in various ways, the best known of which is the coefficient of concordance (Concordance Coefficient, 2017). The authors used the following type of coefficient to calculate:

$W=\frac{S}{\frac{1}{12} m^{2}\left(n^{3}-n\right)-m \sum T_{i}}$

Where in $T_{\bar{i}}=\frac{1}{12} \sum_{i=1}^{L_{1}}\left(t_{i}^{3}-t_{i}\right)$ expert, $t_{l}$ - the number of elements in the $l$-th bunch for the $i$-th expert (the number of repeating elements).

This formula was used to calculate the general concordance of the opinions of experts in their ranking of influence of production costs on the overall results of doing business. It was assumed that the presentation of a single assessment of influence of production costs would make it possible to seek decisions that could improve the conduct of business by all subjects of the general population.

When calculating the overall concordance of the ranked estimates of the impact of production cost items, the number of factors is $n=10$, the number of experts is $m=4$. The matrix of grades for assessing the concordance of experts is presented in Table 3. 
Table 3. Matrix of the ranks of the concordance of all experts

\begin{tabular}{|c|c|c|c|c|c|c|c|}
\hline \multirow[t]{2}{*}{ Factors } & \multicolumn{4}{|c|}{ Experts } & \multirow[t]{2}{*}{ Amount of ranks } & \multirow[t]{2}{*}{$\mathrm{d}$} & \multirow[t]{2}{*}{$\mathrm{d}^{2}$} \\
\hline & 1 & 2 & 3 & 4 & & & \\
\hline $\mathrm{x}_{1}$ & 2 & 1 & 4 & 1 & 8 & -14 & 196 \\
\hline $\mathrm{x}_{2}$ & 8 & 6 & 9 & 9 & 32 & 10 & 100 \\
\hline $\mathrm{x}_{3}$ & 5 & 5 & 10 & 10 & 30 & 8 & 64 \\
\hline $\mathrm{X}_{4}$ & 1 & 9 & 5 & 8 & 23 & 1 & 1 \\
\hline $\mathrm{X}_{5}$ & 4 & 2 & 8 & 7 & 21 & -1 & 1 \\
\hline $\mathrm{X}_{6}$ & 3 & 4 & 2 & 6 & 15 & -7 & 49 \\
\hline $\mathrm{x}_{7}$ & 9 & 3 & 3 & 4 & 19 & -3 & 9 \\
\hline $\mathrm{X}_{8}$ & 10 & 7 & 7 & 5 & 29 & 7 & 49 \\
\hline $\mathrm{X} 9$ & 6 & 8 & 6 & 2 & 22 & 0 & 0 \\
\hline $\mathrm{X}_{10}$ & 7 & 10 & 1 & 3 & 21 & -1 & 1 \\
\hline$\sum$ & 55 & 55 & 55 & 55 & 220 & & 470 \\
\hline
\end{tabular}

Source: Personal Elaboration

Where

$d=\sum x_{i j}-\frac{\sum \sum x_{i j}}{n}=\sum x_{i j}-22$

$W=\frac{12 S}{m^{2}\left(n^{3}-n\right)}$

где $\mathrm{S}=470, \mathrm{n}=10, \mathrm{~m}=4$

$W=\frac{12 \cdot 470}{4^{2}\left(10^{3}-10\right)}=0.356$

$\mathrm{W}=0.356$ says about weak concordance of expert's opinions.

The applied value of the weak link indicator, determined by the concordance coefficient, means that in different types of business, production costs affect overall efficiency with varying impact. Logically, this can be explained by the fact that business processes in different industries are not comparable. There are different types of costs and ways to reduce production costs in each industry.

To determine the nature of the differences, concordance coefficients for the opinions of entrepreneurs and specialists both in manufacturing and services sectors were calculated in the same way (Table 4). 
Similarly, the coefficients for transaction costs were also calculated. The assessment was made on the basis of the cumulative opinion of experts. Comparison between entrepreneurs and specialist also was done.

Table 4. Assessment of consistency of experts' opinions with the coefficient of concordance

\begin{tabular}{|c|c|c|c|}
\hline \multirow{2}{*}{ Concordance coefficient } & All (4) & Manufacturing sector (2) & Services sector (2) \\
\cline { 2 - 4 } & $\begin{array}{c}0.356-\text { weak } \\
\text { concordance }\end{array}$ & 0.6 - medium concordance & 0.818 - high concordance \\
\hline Production costs & 0.564 - medium concordance \\
\hline $\begin{array}{c}\text { Entrepreneurs (managers) in } \\
\text { manufacturing and services }\end{array}$ & 0.533 - medium concordance \\
\hline $\begin{array}{c}\text { Specialists in manufacturing } \\
\text { and services }\end{array}$ & $\begin{array}{c}|c| \\
\text { Transaction costs } \\
\text { concordance }\end{array}$ & 0.472 - weak concordance & 0.815 - high concordance \\
\hline $\begin{array}{c}\text { Entrepreneurs (managers) in } \\
\text { manufacturing and services }\end{array}$ & \multicolumn{3}{|c|}{0.409 - weak concordance } \\
\hline $\begin{array}{c}\text { Specialists in manufacturing } \\
\text { and services }\end{array}$ & 0.91 - high concordance \\
\hline
\end{tabular}

Source: Personal Elaboration

The concordance coefficients demonstrate a low connection in the aggregate assessment (0.356) and high with a separate assessment of the opinions of manufacturing sector experts (0.6) as well as the service sector experts (0.818). It is obvious that production costs are formed to a greater extent under the specifics of production processes and are regulated by the cost management system within business.

Transaction costs calculated for 12 cost items also demonstrate a weak concordance among experts in the whole amount. A high concordance is observed in the assessments of experts in the service sector.

The authors believe that the business processes in the service sector are more similar than in the manufacturing sector. The nature of the service assumes a large share of personal labor. The Kazakhstani service sector is more dependent on rent, utility payments, taxes and credits. The change in the administrative burden on the service sector affects faster and with greater force. This is why concordance in services sector is much higher.

Consistency of opinions on the assessment of transaction costs is higher than for production costs. In the context of a worsening of the market situation, the administrative burden, expressed in transaction costs, increases with respect to the reduced production and is felt by all businesses regardless of industry.

\section{Conclusions}

For populist purposes, ranking is used often in determining of priority areas for protecting entrepreneurs' rights. The data obtained are given an unconditional estimate, without specifying the degree of concordance of opinions. This leads to a decrease in the quality of decisions.

Having considered the values of the concordance coefficients calculated to assess the consistency of the opinions of experts of various categories, a number of practical conclusions can be drawn. 
The International Journal

ENTREPRENEURSHIP AND SUSTAINABILITY ISSUES

ISSN 2345-0282 (online) http://jssidoi.org/jesi/

2018 Volume 6 Number 1 (September)

http://doi.org/10.9770/jesi.2018.6.1(24)

When studying the factors that influence the development of the national business, a generalization of the assessments of experts is made without taking into account the consistency (concordance), which may actually be weak.

Researches of production costs should be conducted separately by industry. The results of examining the opinions of experts in the service sector give more consistent and correct opinions. Estimates of representatives of the service sector are more homogeneous.

Entrepreneurs and managers are less harmonized in their assessments, their conclusions are more political than objective. They reflect intentions, not an analysis of the situation. Experts rely on factual data, their attributive estimates are close to quantitative.

Due to the specifics of the Kazakhstan market, a number of production costs have more transactional nature rather than productive. The cost of fuel, electricity and water is formed on a monopolistic basis from quasi-public suppliers (Atameken.kz, 2017).The absence of market competition turns these costs into transaction fees and leads to the primary need for government regulation.

Based on the results of the analysis, 110 recommendations for reducing of costs were proposed, that require amendments to legislation. The number of proposed amendments to the legislative acts is 66, including:

- into Codes -37

- into Laws - 29

- into regulations -19

- into rules -25

The total amount of costs assumed to be reduced after legislation changes adoption - KZT580,6 billion (USD 1,8 billion)

\section{References}

A draft of law for reducing the cost that impede business http://atameken.kz/ru/news/27353-u-kazahstanskih-predprinimatelej-est-rupor CEO SURVEY 2016. https://forbes.kz/leader/ceo_survey_2o16

Chepurenko A. 2017. Entrepreneurial activity in post-socialist countries: methodology and research limitations, Foresight and STI Governance 11(3): 11-24. http://dx.doi.org/10.17323/2500-2597.2017.3.11.24

Concordance Coefficient: example calculation and formula. http://fb.ru/article/349619/koeffitsient-konkordatsii-primer-rascheta-i-formulachto-takoe-koeffitsient-konkordatsii

Giriūnienè, G.; Giriūnas, L. 2017. Identification of the complex tax system evaluation criteria: theoretical aspect, Journal of Security and Sustainability Issues 7(2): 257-265. https://doi.org/10.9770/jssi.2017.7.2(7)

Ketokivi M., Mahoney J., Transaction Cost Economics as a Theory of the Firm, Management, and Governance in Oxford Research Encyclopedia of Business and Management October 2017 http://dx.doi.org/10.1093/acrefore/9780190224851.013.6

Narkuniené, J.; Ulbinaite, A. 2018. Comparative analysis of company performance evaluation methods, Entrepreneurship and Sustainability Issues 6(1): 125-138. http://doi.org/10.9770/jesi.2018.6.1(10)

OECD Integrity Scan of Kazakhstan. Preventing Corruption for a Competitive Economy. 2017 http://www.oecd.org/countries/kazakhstan/oecd-integrity-scan-of-kazakhstan-9789264272880-en.htm

Paneyah E. 2011. Formal rules and informal institutions of their application in the Russian economic practice, Journal of Economic Sociology 2(4) https://ecsoc.hse.ru/en/2001-2-4/annot.html\#doc_26594822 
The International Journal

ENTREPRENEURSHIP AND SUSTAINABILITY ISSUES

ISSN 2345-0282 (online) http://jssidoi.org/jesi/

2018 Volume 6 Number 1 (September)

http://doi.org/10.9770/jesi.2018.6.1(24)

State of the Nation Address by the President of the Republic of Kazakhstan Nursultan Nazarbayev, January 10 , 2018. http://www.akorda.kz/en/addresses/addresses_of_president/state-of-the-nation-address-by-the-president-of-the-republic-of-kazakhstannursultan-nazarbayev-january-10-2018

The Prime Minister of Kazakhstan, Official website 2018; https://primeminister.kz/en/news/all/bakitzhan-sagintaev-o-sovmestnoi-rabote-snpp-atameken-na-segodnya-sformirovana-splochennaya-komanda-16722

Tvaronavičienė, M.; Nesterova, K.; Kováčik, V. 2017. Energy security and long-term energy efficiency: case of selected counties, Journal of Security and Sustainability Issues 7(2): 349-357. https://doi.org/10.9770/jssi.2017.7.2(14)

Elena PETRENKO is Doctor of economics, professor, Plekhanov Russian University of Economic, Professor of the Department of Management Theory and Business Technologies, Moscow. Expert Consultant of the European Bank for Reconstruction and Development in Kazakhstan, Karaganda city. Research interests: modern management problems, entrepreneurship development, post-industrial economy manager, creative industries.

ORCHID ID: 0000-0001-6892-2392

Sergey PIZIKOV is graduate student. Founadion for Informational Support for Society Development East Kazakhstan, UstKamenogorsk city. Research interests: Development and management of civil society, interaction with the state, monitoring of public services.

ORCID ID: 0000-0002-2527-1232

Nurlan MUKALIYEV is graduate student. Director, "VIMA" LLP, Astana city. Research interests: management of innovations, lean production, innovative entrepreneurship.

ORCID ID: 0000-0002-3710-7747

Anuar MUKAZHAN is graduate student Tsesnabank, Kazakhstan, Astana city. Research interests: blockchain, development of banking technologies, knowledge economy, management of network models, economic risks

ORCID ID: 0000-0001-7285-8995

Register for an ORCID ID:

https://orcid.org/register

Copyright (C) 2018 by author(s) and VsI Entrepreneurship and Sustainability Center

This work is licensed under the Creative Commons Attribution International License (CC BY).

http://creativecommons.org/licenses/by/4.0/

(c) () Open Access 